\title{
Performance of Mulberry Varieties for their Suitability in Sericulture
}

\author{
Amanpreet Kaur*, J. S. Brar and Karmjit Singh \\ Guru Kashi University, Talwandi Sabo (Punjab), India \\ *Corresponding author
}

\begin{abstract}
A B S T R A C T
\section{Keywords}

Catkin

inflorescence,

Oviposition,

Fecundity,

Sericulture,

Longevity, Instars,

dfls, chawki rearing

Article Info

Accepted:

18 August 2020

Available Online:

10 September 2020

Six varieties of mulberry were compared to study their influence on growth and development of silkworm (Bombyx mori) under laboratory conditions. The total larval duration of $B$. mori was observed to be $17.0 \pm 2.3,19.4 \pm 2.5,16.2 \pm 2.7,27.0 \pm 2.4,24.2$ +3.2 and $26.4+2.5$ days, respectively on S-1635, S-146, M-5, S-36, V-1 \& Pb. local). The results indicated that the varieties were divisible into two groups, on the basis of number of days taken to complete larval stage. The varieties, viz. S-1635, S-146 \& M-5 ( $\mathrm{G}-1$ ) exhibited fast growth of the silkworms, whereas the varieties, viz. S-36, V-1 \& Pb local $-(G-2)$ demonstrated slow growth of the larvae. The individual instars, fed on mulberry leaves of G-1 cultivars, took lesser number of days than those fed on G-2 cultivars. The average pupal duration of $B$. mori was observed to be $8.7 \pm 2.0,8.5 \pm 2.0$, $9.4 \pm 2.5,11.8 \pm 2.7,12.5 \pm 1.7$ and $13.5 \pm 2.6$ days, respectively, on S-1635, S-146, M-5, S-36, V-1 and $\mathrm{Pb}$. local. The studies, thus revealed faster development of pupae on G-1 than that on G-2 group of mulberry cultivars. The egg laying period was longer in the females reared on G-1 cultivars than G-2 group of mulberry cultivars, indicative of long oviposition period of females. The mean oviposition period was found to be $7.9 \pm 2.5,6.2$ $\pm 2.6,8.5 \pm 3.5,4.0 \pm 2.8,4.5 \pm 2.5$ and 4.4 days, respectively, on S-1635, S-146, M-5, S$36, \mathrm{~V}-1$ and $\mathrm{Pb}$. local. Further it was observed that, female moths reared on G-1 cultivars, exhibited high fecundity and laid more number of eggs than those raised from G-2 cultivars. The average number of eggs per female were found to be $325 \pm 10.5,360 \pm 6.5$, $310+5.6,150+9.5,250+5.6,175+4.5$, respectively, on S-1635, S-146, M-5, S-36, V-1 and $\mathrm{Pb}$. local. Quick growth and better health of silkworms fed on different mulberry cultivars, also revealed that G-1 cultivars (S-1635, S-146, M-5) were the preferred food hosts.
\end{abstract}

\section{Introduction}

Mulberry (Morus alba L.) is a fast growing deciduous woody perennial dioecious plant having deep root system. The leaves are simple, alternate, petiolate, entire or lobed. The inflorescence is catkin and auxillary with pendent or drooping peduncles. The ovary is single celled, the stigma bifid, usually wind pollinated, but sometimes insect pollinated too. In India, the mulberry is grown under varied climatic conditions ranging from temperate to tropical, covering Karnataka, Andhra Pradesh and Tamil Nadu states. In the sub-tropical zone, West Bengal, Himachal Pradesh and the north-eastern states have 
major areas under mulberry cultivation. The total area of mulberry in the country is around 282244 ha. Mulberry foliage is the only food for the silkworm and the major economic component in sericulture. The quality and quantity of leaves have a direct bearing on cocoon harvest. The agro climatic conditions in some pockets of the state are congenial for cultivation of mulberry silk in Punjab and therefore, the state sponsored project was started on silk production with high silk content and improved quality. The main objectives of the scheme were to promote bivoltine sericulture and to harness the available natural resources in the state. Marginal and landless farmers were adopted silk farming for additional income involving women in work force.

Sericulture is an agro-based labour intensive cottage industry, involving mass rearing of silk worms in order to obtain silk. It has emerged as an important economic activity, becoming increasingly popular in several parts of the country because of its short gestation period, quick recycling of resources (Anonymous, 2006). The Indian silk industry is unique in producing five types of silk viz., Mulberry, Eri, Muga, tropical and temperate Tassar silks. However, the mulberry silk is more popular and widely used in the country. Mulberry leaves are the exclusive source of nutrition for growth and development of silkworms. The quality of leaves fed to silkworm is the prime factor for determining cocoon production. Mulberry leaves containing high protein and amino acids content, influence the shell weight of cocoon (Machii and Katagiri, 1991). Variety of mulberry, agronomic practices and plant protection measures, determine quality of leaves. Nutritional composition of mulberry leaves varies with different cultivars and that influences larval growth of silkworms and cocoon production. The quality of mulberry leaves and environmental conditions influence the dietary efficiency and growth of silkworm (Rahmathulla et al., 2005). The performance of any mulberry variety with respect to leaf quality and cocoon production varies with agro-climatic conditions and cultivation practices. Physical and chemical properties of leaves directly influence the amount of leaf consumption and digestion (Das and Vijayaraghavan, 1990).

Sericulture is an eco-friendly and agroforestry oriented trade, comprising cultivation of mulberry plant varieties, rearing of silkworms, and production of silk. Most of the marketable silk around the world is being produced from the mulberry silkworm, Bombyx mori (Yogananda-Murthy et al., 2013). Silk worm is an essentially monophagous and host plant-specific insect that feeds solely on mulberry leaves. India has rich resources of mulberry varieties that are traditionally cultivated. Besides the influence of environmental factors, the silk productivity is related to the quantity and quality of mulberry leaves (Nagaraju, 2002). Development of silkworm is greatly influenced by nutrient composition of the mulberry leaves, which has been reported as the determining factor for the quality of silk (Jyothi et al., 2014). The amount of food consumed and the quantity digested by the silkworms have a direct effect on its physiological performance and silk production. The protein content of mulberry leaves is the paramount nutritional factor in determining the life cycle performance of silkworm (Pillai and Jolly, 1985). The studies on different varieties of mulberry were mainly focused on the growth, duration of life stages and reproduction of the silkworm. In the present study, an attempt has been made to assess the performance of $B$. mori on four mulberry varieties to identify the most suitable hosts with regard to the economic traits of Bombyx mori silkworm in Punjab at Guru Kashi University in 2019. Integrated 
sericulture programme consisting of multiple sericulture crops and intercropping of cereal crops, without having adverse affect on mulberry leaf production, were the added objectives to popularise sericulture in Punjab.

\section{Materials and Methods}

The success of sericulture industry is mainly based on leaf quality and appropriate environmental conditions for silkworm rearing. Mulberry leaves are exclusive source of nutrition for silkworm. The study was aimed to assess the impact of different mulberry varieties namely, S-1635, S-146, M5, S-36, V-1 and Punjab local (Table 1). Nursery saplings were procured from mulberry gardens of CSR Sujanpur. Cultivation of mulberry plants was done as per the package of practices. After gestation period of two years at GKU, mulberry garden was established to demonstrate feasibility of multiple sericulture crops and inter cropping with wheat and mustard. To promote silk worm rearing and to allow optimum production and utilization of mulberry plants as silkworm food, the knowledge on varieties of mulberry plant available, is imperative in Punjab. The present study, therefore, aimed at investigating the influence of different varieties of mulberry leaves on performance of rate and development silkworm, cocooning, fecundity and fertility of eggs of silkworm.

The investigations were carried out in the entomology laboratory of GKU. Since temperature and humidity have great bearing on the growth and health of silkworms, the ideal conditions were maintained during the course of studies. Temperature of $24-27$ degrees centigrade and $70-90 \%$ relative humidity were maintained in the laboratory. Disease Free Layings (dfls) of bivoltine hybrid race (CSR2xCSR4) were procured from Central Silk Board, Dehradun during
2018 and 2019. The mulberry leaves were harvested from the mulberry plantation in the morning and evening hrs for the feeding of bivoltine strain of Bombyx mori. The newly hatched larvae were brushed in to rearing trays and provided chopped tender leaves as food and chawki rearing was carried out.

The growth and cocoon characteristics of silkworms fed on leaves of different mulberry varieties were studied. Mulberry leaves of the six varieties namely, S-1635, S-146, M-5, S36, V-1 and Punjab local, were fed individually to the larvae for four times in a day (6:00 a.m., 11:00 a.m., 4:00 p.m. and 10:00 p.m.). Three rearing trays, each containing 100 larvae, were maintained for each variety of mulberry leaves. Standard uniform rearing procedure of silkworms, was followed in all treatments, except the food (mulberry cultivars). Daily observations were taken to watch larval health and unhealthy or dead larvae removed periodically. Fresh, clean and chopped mulberry leaves were provided as food up to 3rd instar, while the later instars were fed on sound/unchopped leaves of mulberry. Full grown larvae were picked up manually and mounted on bamboo spinning tray. The larval measurements of different instars and other stages were recorded as per method (s) of Singh, 2019.

The incubation period was recorded on 20 freshly laid eggs and they were observed daily till hatching. The larvae were provided with fresh food containing fine chopped mulberry leaves of different varieties grown in the university garden and duration of each instar was recorded. The period from cocoon formation to adult emergence was counted as the pupal period. The adult longevity of 20 silk moths was recorded from the date of adult emergence till death. The effect of different mulberry varieties and seasons on growth and cocoon characteristics of $B$. mori was assessed based on various morphometrics 
and qualitative parameters. Morphometric studies on B. mori were made with the help of vernier calliper, graph paper and metric scale suiting to the chosen life stages, like larva, cocoon, pupa and adult (Singh, 2019). The pupae were taken out by cutting cocoon shells with fine sharp blades. To compare fecundity of females, live adults of both sexes were confined in cardboard boxes for mating. After mating, the females were isolated for laying eggs.

\section{Results and Discussion}

Leaves from six varieties of mulberry ( $\mathrm{S}$ 1635, S-146, M-5, S-36, V-1 and Punjab local) were fed to the silk moth larvae and their influence on the larval weight, filament length and larval protein content was studied under laboratory conditions. The total larval duration of $B$. mori was observed to be $17.0 \pm 2.3, \quad 19.4 \pm 2.5, \quad 16.2 \pm 2.7, \quad 27.0 \pm 2.4$, $24.2 \pm 3.2$ and $26.4 \pm 2.5$ days, respectively on various cultivars of mulberry, viz. S-1635, S146, M-5, S-36, V-1 and Punjab local (Table $2)$. The results indicated that on the basis of number of days for completing larval stage, the varieties were divisible in to two groups. G-1 comprising of 3 cultivars (S-1635, S-146, M-5) exhibited quick larval growth of silkworms, whereas the worms fed on G-2 group ( $\mathrm{S}-36, \mathrm{~V}-1, \mathrm{~Pb}$. local) took longer days to complete, demonstrating thereby slow growth for the larvae.

The duration of individual instars was studied by feeding them freshly chopped mulberry leaves up to 3rd instar and the grown up caterpillars were provided whole (unchopped) leaves to feed upon. The individual instars, fed on mulberry leaves of G-1cultivars ( $\mathrm{S}$ 1635, S-146, M-5)took less number of days than those fed on G-1 cultivars of mulberry (Table 2). The pupal duration of $B$. mori was observed to be $8.7 \pm 2.0,8.5 \pm 2.0,9.4 \pm 2.5$, $11.8 \pm 2.7, \quad 12.5 \pm 1.7$ and $13.5 \pm 2.6$ days, respectively on the test cultivars of mulberry, viz. S-1635, S-146, M-5, S-36, V-1 and Pb. local. The results provided an indication that the pupal duration was shorter on G-1 group than the G-2 group of mulberry cultivars, revealing thereby faster development of pupae on G-1 than that on G-2 group of cultivars (Table 2).

Sunday, 2015 reported that there were significant differences between varieties of mulberry leaves on larval mortality and cocooning, however, there was no significant effect on pupal weight and the egg hatchability. Ruth et al., 2019 reported that variety S-1635 performed the best for rearing of $B$. mori in terms of growth and economic parameters and has potential to enhance qualities of silk. Sujathamma et al., (2001) evaluated mulberry genotypes in Andhra Pradesh and recommended two varieties ( $\mathrm{Tr}$ 10 and $\mathrm{Mr}-2$ ) for commercial cultivation. Bohidar et al., (2007) reported effect of different mulberry genotypes on the economic parameters of silkworm in Orissa and made suggestion for including mulberry varieties $\mathrm{V}$ 1 and S-36 in silk production. Present study also confirmed that S-1635 mulberry variety gave better results as compared to S-36 and $\mathrm{V}-1$.

The female silk moths were longer lived and they were bigger sized than their male counter parts. Various test cultivators of mulberry, however, didn't provide any evidence of size variation and adult longevity of $B$. mori. Oviposition period was $7.9 \pm 2.5,6.2 \pm 2.6$, $8.5 \pm 3.5,4.0 \pm 2.8,4.5 \pm 2.5$ and 4.4 days, respectively on S-1635, S-146, M-5, S-36, V1 and $\mathrm{Pb}$. local. It was observed that egg laying period was longer in females reared on G-1 cultivars than G-2 group of mulberry cultivars, indicative of long oviposition period of females (Table 2). It was observed that female moths reared on G-1 cultivars, exhibited high fecundity and laid more 
number of eggs than those raised from G-2 cultivars. The average number of eggs per female were found to be $325 \pm 10.5,360 \pm$ $6.5,310 \pm 5.6,150 \pm 9.5,250 \pm 5.6,175 \pm$ 4.5 , respectively, on S-1635, S-146, M-5, S$36, \mathrm{~V}-1$ and $\mathrm{Pb}$. local. It was thus concluded that leaves of G-1 cultivars were the better options for inclusion in the state run sericulture programme.

Morphometric observations of individual instars of silkworm were recorded as per the technique (s) followed by Singh, 2019.
Length and breadth of 20 larval instars were measured in $\mathrm{mm}$ in each cultivar of mulberry and averages were calculated as per standard statistical procedure Panse and Sukhatme (1967). Measurements of individual instars, revealed that the instars reared on leaves of G-1 cultivars [(-1635, S-146, M-5), exhibited higher values of body measurements (length and breadth] than those fed on leaves of G-2 cultivars (S-36, V-1, Pb. local). It became evident from the results that the larvae fed on G-1 cultivars were healthier than the ones reared on G-2 group (Table 3).

Table.1 Mulberry varieties used in the studies (Dhar et al., 2014)

\begin{tabular}{|c|c|c|}
\hline Sr No. & Name of variety & Key characters \\
\hline \multirow[t]{6}{*}{1} & $S-1635$ & $\begin{array}{l}\text { It is a triploid, variety with high leaf yield, suited for assured } \\
\text { irrigated conditions, planting through saplings and wide } \\
\text { spacing }(60 \mathrm{~cm} \times 60 \mathrm{~cm}) \text {. It fares well throughout the country. }\end{array}$ \\
\hline & $S-146$ & $\begin{array}{l}\text { It is belongs to Morus alba, the fruits are white, native to } \\
\text { China, cultivated as food for silkworms. With the progress of } \\
\text { silk making art this variety spread to Japan, India, and } \\
\text { Europe, travelers took it to North America with the hope of } \\
\text { spawning a silk industry. }\end{array}$ \\
\hline & M -5 & $\begin{array}{l}\text { It is a diploid, belongs to Morus indica. Widely cultivated in } \\
\text { Southern India, selection from Mysore local variety. } \\
\text { Inflorescence and sorosis: profuse flowering, medium leaf } \\
\text { maturity, high yielder under irrigated conditions. High rooting } \\
\text { ability and wide adaptability. Resistant to leaf spot, leaf rust and } \\
\text { powdery mildew. }\end{array}$ \\
\hline & $S-36$ & $\begin{array}{l}\text { Belongs to } M \text {. indica, spreading type, leaves large, entire, } \\
\text { cordate, pale green, smooth and glassy, grows well in red loamy } \\
\text { soil and ideal for chawki rearing. This variety has light green, } \\
\text { heart shaped leaves. Sapling plantation recommended because of } \\
\text { moderate rooting ability. }\end{array}$ \\
\hline & $\mathrm{V}-1$ & $\begin{array}{l}\text { The variety is characterized by erect branches and grayish stem } \\
\text { colour. Leaves are smooth, succulent, large, entire and ovate } \\
\text { with truncate base. suitable for bivoltine silkworm rearing, Good } \\
\text { agronomic characters like high rooting, fast growth and high } \\
\text { yield; high sprouting and rooting ability }\end{array}$ \\
\hline & Punjab local & $\begin{array}{l}\text { Characterized by small sized } 5 \text { lobed leaves, with having hard } \\
\text { and rough consistency. Moderate branching and tree type. } \\
\text { Available growing on road sides and canal banks and field } \\
\text { boundaries }\end{array}$ \\
\hline
\end{tabular}


Table.2 Impact of mulberry cultivars on life span and fecundity of Bombyx mori

\begin{tabular}{|c|c|c|c|c|c|c|}
\hline \multirow[t]{2}{*}{ Life stage } & \multicolumn{6}{|c|}{ Life duration (days) and fecundity on mulberry cultivars } \\
\hline & S-1635 & S-146 & M-5 & S-36 & V-1 & Punjab local \\
\hline 1st instar & $\begin{array}{c}3.6 \pm 0.5 \\
* *(3-4)\end{array}$ & $\begin{array}{l}4.3 \pm 0.4 \\
(4-5)\end{array}$ & $\begin{array}{l}4.8 \pm 0.4 \\
(4-5)\end{array}$ & $\begin{array}{l}5.75 \pm 1.48 \\
(4-5)\end{array}$ & $\begin{array}{l}6.3 \pm 0.5 \\
(4-6)\end{array}$ & $\begin{array}{c}5.6 \pm 0.6 \\
(2-6)\end{array}$ \\
\hline 2nd instar & $\begin{array}{c}4.7 \pm 0.6 \\
(3-5)\end{array}$ & $\begin{array}{l}6.5 \pm 0.5 \\
(5-7)\end{array}$ & $\begin{array}{l}4.6 \pm 0.5 \\
(4-5)\end{array}$ & $\begin{array}{c}6.75 \pm 2.45 \\
(3-8)\end{array}$ & $\begin{array}{l}4.5 \pm 0.7 \\
(5-6)\end{array}$ & $\begin{array}{c}4.6 \pm 0.8 \\
(4-6)\end{array}$ \\
\hline 3rd instar & $\begin{array}{l}3.6 \pm 0.7 \\
(4-6)\end{array}$ & $\begin{array}{l}7.8 \pm 0.7 \\
(5-8)\end{array}$ & $\begin{array}{l}5.3 \pm 1.3 \\
(4-6)\end{array}$ & $\begin{array}{c}5.80 \pm 1.50 \\
(4-5)\end{array}$ & $\begin{array}{l}5.2 \pm 1.4 \\
(3-7)\end{array}$ & $\begin{array}{c}6.6 \pm 0.5 \\
(4-7)\end{array}$ \\
\hline 4th instar & $\begin{array}{l}4.8 \pm 1.5 \\
(3-6)\end{array}$ & $\begin{array}{l}7.3 \pm 0.8 \\
(6-7)\end{array}$ & $\begin{array}{l}4.8 \pm 0.5 \\
(2-5)\end{array}$ & $\begin{array}{c}6.70 \pm 0.48 \\
(5-7)\end{array}$ & $\begin{array}{l}5.7 \pm 1.2 \\
(4-7)\end{array}$ & $\begin{array}{c}5.6 \pm 0.6 \\
(5-6)\end{array}$ \\
\hline 5th instar & $\begin{array}{c}4.0 \pm 1.4 \\
(5-6)\end{array}$ & $\begin{array}{c}6.2 \pm 0.5 \\
(6-7)\end{array}$ & $\begin{array}{c}4.6 \pm 0.7 \\
(5-7)\end{array}$ & $\begin{array}{l}5.75 \pm 1.25 \\
(5-6)\end{array}$ & $\begin{array}{c}4.6 \pm 1.5 \\
(4-9)\end{array}$ & $\begin{array}{c}7.6 \pm 0.7 \\
(5-8)\end{array}$ \\
\hline $\begin{array}{c}\text { Total larval } \\
\text { period }\end{array}$ & $\begin{array}{l}17.0 \pm 2.3 \\
(18-24)\end{array}$ & $\begin{array}{l}19.4 \pm 2.5 \\
(16-20)\end{array}$ & $\begin{array}{l}\mathbf{1 6 . 2} \pm \mathbf{2 . 7} \\
(15-18)\end{array}$ & $\begin{array}{l}\mathbf{2 7 . 0} \pm \mathbf{2 . 4} \\
(23-28)\end{array}$ & $\begin{array}{l}\mathbf{2 4 . 2}+3.2 \\
(17-19)\end{array}$ & $\begin{array}{l}\mathbf{2 6 . 4} \pm \mathbf{2 . 5} \\
(23-29)\end{array}$ \\
\hline Pupa & $\begin{array}{l}8.7 \pm 2.0 \\
(9-12)\end{array}$ & $\begin{array}{c}8.5 \pm 2.0 \\
(10-12)\end{array}$ & $\begin{array}{c}9.4 \pm 2.5 \\
(10-11)\end{array}$ & $\begin{array}{c}11.8 \pm 2.7 \\
(9-12)\end{array}$ & $\begin{array}{c}12.5 \pm 1.7 \\
(8-9)\end{array}$ & $\begin{array}{l}13.5 \pm 2.6 \\
(8-10)\end{array}$ \\
\hline male longevity & $\begin{array}{c}\mathbf{5 . 6} \pm 2.5 \\
(5-8)\end{array}$ & $\begin{array}{c}5.5 \pm 0.8 \\
(6-7)\end{array}$ & $\begin{array}{c}6.4 \pm 3.2 \\
(4-6)\end{array}$ & $\begin{array}{c}5.8+2.5 \\
(5-8)\end{array}$ & $\begin{array}{c}6.50 \pm 2.5 \\
(4-7)\end{array}$ & $\begin{array}{c}7.50 \pm 2.5 \\
(6-7)\end{array}$ \\
\hline female longevity & $\begin{array}{c}7.9 \pm 2.5 \\
(6-9)\end{array}$ & $\begin{array}{l}6.5 \pm 0.6 \\
(7-9)\end{array}$ & $\begin{array}{l}7.9 \pm 1.5 \\
(6-8)\end{array}$ & $\begin{array}{c}6.8 \pm 2.1 \\
(6-8)\end{array}$ & $\begin{array}{c}7.6 \pm 2.5 \\
(6-7)\end{array}$ & $\begin{array}{l}8.7 \pm 2.2 \\
(8-10)\end{array}$ \\
\hline $\begin{array}{l}\text { Egg laying pd. } \\
\text { (days) }\end{array}$ & $\begin{array}{c}7.9 \pm 2.5 \\
(6-8)\end{array}$ & $\begin{array}{c}6.2 \pm 2.6 \\
(5-7)\end{array}$ & $\begin{array}{l}8.5 \pm 3.5 \\
(7-10)\end{array}$ & $\begin{array}{c}4.0 \pm 2.8 \\
(2-5)\end{array}$ & $\begin{array}{c}4.5 \pm 2.5 \\
(3-6)\end{array}$ & $\begin{array}{c}4.4 \\
(3-5)\end{array}$ \\
\hline $\begin{array}{c}\text { Fecundity } \\
\text { (Eggs/female) }\end{array}$ & $\begin{array}{l}325 \pm 10.5 \\
(235-490)\end{array}$ & $\begin{array}{l}360 \pm 6.5 \\
(300-410)\end{array}$ & $\begin{array}{l}310 \pm 5.6 \\
(280-(340)\end{array}$ & $\begin{array}{l}150 \pm 9.5 \\
(95-275)\end{array}$ & $\begin{array}{l}250 \pm 5.6 \\
(151-239)\end{array}$ & $\begin{array}{c}175 \pm 4.5 \\
(150-200)\end{array}$ \\
\hline
\end{tabular}

*Data (Mean \pm S.D.) are based on 20 observations recorded in each case

**Figures in parenthesis are the range values

Table.3 Morphometric measurements ( $\mathrm{mm}$ ) of Bombyx mori, reared on different mulberry cultivars

\begin{tabular}{|c|c|c|c|c|c|c|c|c|c|c|c|c|}
\hline \multirow{3}{*}{$\begin{array}{c}\text { Instar/S } \\
\text { tage }\end{array}$} & \multicolumn{12}{|c|}{ *Body measurements of silkworm } \\
\hline & \multicolumn{2}{|c|}{$S-1635$} & \multicolumn{2}{|c|}{ S-146 } & \multicolumn{2}{|c|}{ M-5 } & \multicolumn{2}{|c|}{ S-36 } & \multicolumn{2}{|c|}{ V-1 } & \multicolumn{2}{|c|}{ Punjab local } \\
\hline & $\mathbf{L}$ & B & $\mathbf{L}$ & B & $\mathbf{L}$ & B & $\mathbf{L}$ & B & $\mathbf{L}$ & B & $\mathbf{L}$ & B \\
\hline $1^{\text {st }}$ & $\begin{array}{c}1.4 \\
\pm 1.0\end{array}$ & $\begin{array}{c}0.5 \\
\pm 0.2\end{array}$ & $\begin{array}{c}1.2 \\
\pm 1.5\end{array}$ & $\begin{array}{c}0.6 \\
\pm 0.2\end{array}$ & $\begin{array}{c}1.5 \\
\pm 0.7\end{array}$ & $\begin{array}{c}0.4 \\
\pm 0.2\end{array}$ & $\begin{array}{c}1.2 \\
\pm 0.3\end{array}$ & $\begin{array}{c}0.3 \\
\pm 0.2\end{array}$ & $\begin{array}{c}1.4 \\
\pm 0.5\end{array}$ & $\begin{array}{c}0.4 \\
\pm 1.2\end{array}$ & $\begin{array}{c}1.2 \\
\pm 0.4\end{array}$ & $\begin{array}{c}0.3 \\
\pm 1.2\end{array}$ \\
\hline $2^{\text {nd }}$ & $\begin{array}{c}8.1 \\
\pm 0.7\end{array}$ & $\begin{array}{c}1.5 \\
\pm 0.5\end{array}$ & $\begin{array}{c}7.1 \\
\pm 1.7\end{array}$ & $\begin{array}{c}1.8 \\
\pm 0.6\end{array}$ & $\begin{array}{c}8.1 \\
\pm 0.7\end{array}$ & $\begin{array}{c}1.5 \\
\pm 0.4\end{array}$ & $\begin{array}{c}6.2 \\
\pm 0.8\end{array}$ & $\begin{array}{c}1.6 \\
\pm 0.4\end{array}$ & $\begin{array}{c}5.1 \\
\pm 0.8\end{array}$ & $\begin{array}{c}1.8 \\
\pm 1.4\end{array}$ & $\begin{array}{c}5.4 \\
\pm 1.5\end{array}$ & $\begin{array}{c}1.4 \\
\pm 1.2\end{array}$ \\
\hline $3^{\text {rd }}$ & $\begin{array}{r}13.6 \\
\pm 1.2\end{array}$ & $\begin{array}{c}2.4 \\
\pm 0.4\end{array}$ & $\begin{array}{r}13.7 \\
\pm 1.5\end{array}$ & $\begin{array}{c}2.5 \\
\pm 0.8\end{array}$ & $\begin{array}{r}13.7 \\
\pm 1.5\end{array}$ & $\begin{array}{c}2.1 \\
\pm 0.4\end{array}$ & $\begin{array}{r}11.5 \\
\pm 1.4\end{array}$ & $\begin{array}{c}3.1 \\
\pm 0.5\end{array}$ & $\begin{array}{r}11.5 \\
\pm 1.5\end{array}$ & $\begin{array}{c}3.5 \\
\pm 1.2\end{array}$ & $\begin{array}{l}10.6 \\
\pm 1.5\end{array}$ & $\begin{array}{c}3.1 \\
\pm 1.4\end{array}$ \\
\hline $4^{\text {th }}$ & $\begin{array}{r}34.0 \\
\pm 2.5\end{array}$ & $\begin{array}{c}2.6 \\
\pm 0.5\end{array}$ & $\begin{array}{r}32.5 \\
\pm 2.5\end{array}$ & $\begin{array}{c}2.6 \\
\pm 0.3\end{array}$ & $\begin{array}{l}34.0 \\
\pm 2.5\end{array}$ & $\begin{array}{c}2.3 \\
\pm 0.3\end{array}$ & $\begin{array}{r}27.9 \\
\pm 2.6\end{array}$ & $\begin{array}{c}3.3 \\
\pm 0.7\end{array}$ & $\begin{array}{r}26.6 \\
\pm 2.1\end{array}$ & $\begin{array}{c}2.3 \\
\pm 1.3\end{array}$ & $\begin{array}{l}25.2 \\
\pm 2.5\end{array}$ & $\begin{array}{c}3.2 \\
\pm 2.0\end{array}$ \\
\hline $5^{\text {th }}$ & $\begin{array}{l}57.6 \\
\pm 4.2\end{array}$ & $\begin{array}{c}3.5 \\
\pm 1.5\end{array}$ & $\begin{array}{r}56.6 \\
\pm 4.2\end{array}$ & $\begin{array}{c}3.4 \\
\pm 1.0\end{array}$ & $\begin{array}{l}58.5 \\
\pm 4.2\end{array}$ & $\begin{array}{c}3.5 \\
\pm 1.2\end{array}$ & $\begin{array}{r}38.5 \\
\pm 4.2\end{array}$ & $\begin{array}{c}3.5 \\
\pm 1.0\end{array}$ & $\begin{array}{r}30.5 \\
\pm 4.1\end{array}$ & $\begin{array}{c}2.5 \\
\pm 1.0\end{array}$ & $\begin{array}{r}30.4 \\
\pm 2.1\end{array}$ & $\begin{array}{c}3.0 \\
\pm 1.5\end{array}$ \\
\hline Cocoon & $\begin{array}{c}32 \\
. \pm 2.0\end{array}$ & $\begin{array}{r}18.2 \\
\pm 2.2\end{array}$ & $\begin{array}{l}30.5 \\
\pm 2.5\end{array}$ & $\begin{array}{r}16.0 \\
\pm 2.2\end{array}$ & $\begin{array}{l}34.6 \\
\pm 2.0\end{array}$ & $\begin{array}{r}16.2 \\
\pm 1.2\end{array}$ & $\begin{array}{l}28.7 \\
\pm 2.0\end{array}$ & $\begin{array}{r}12.0 \\
\pm 2.2\end{array}$ & $\begin{array}{l}27.0 \\
\pm 1.5\end{array}$ & $\begin{array}{c}12.2 \pm \\
2.2\end{array}$ & $\begin{array}{r}25.5 \\
\pm 2.0\end{array}$ & $\begin{array}{c}11.0 \pm \\
2.2\end{array}$ \\
\hline Pupa & $\begin{array}{r}20.0 \\
\pm 1.9\end{array}$ & $\begin{array}{c}6.7 \\
\pm 1.0\end{array}$ & $\begin{array}{r}19.0 \\
\pm 1.8\end{array}$ & $\begin{array}{c}6.8 \\
\pm 1.0\end{array}$ & $\begin{array}{r}19.0 \\
\pm 2.0\end{array}$ & $\begin{array}{c}6.7 \\
\pm 1.0\end{array}$ & $\begin{array}{r}16.8 \\
\pm 1.5\end{array}$ & $\begin{array}{c}6.7 \\
\pm 1.0\end{array}$ & $\begin{array}{r}14.6 \\
\pm 1.2\end{array}$ & $\begin{array}{c}6.7 \\
\pm 1.0\end{array}$ & $\begin{array}{l}14.4 \\
\pm 1.4\end{array}$ & $\begin{array}{c}6.7 \\
\pm 1.0\end{array}$ \\
\hline
\end{tabular}

* Data (mean \pm S.D, ) are based on 20 observations recorded in each case 
Quick growth and better health of silkworms fed on different mulberry cultivars, also revealed that G-1 cultivars (S-1635, S-146, M-5) were the preferred food hosts and may contribute to impacting cocoon characteristics. Cocoon length and breadth were measured in mm, with the help of metric scale. It was found the cocoons developed from the larvae after feeding on G-1 group of cultivars ((S-1635, S-146, M-5), were large sized as compared to those fed on G-2 cultivars (S-36, V-1, Pb. local). The respective values for cocoon length and breadth in G-1 cultivars were found to be 32.0/18.2, $30.5 / 16.0,34.6 / 16.2 \mathrm{~mm}$. Accordingly, the cocoons developed in G-2 group of mulberry cultivars, were recorded as 28.7/12.0, 27.0/12.2 and 25.5/11.0 mm (Table 3). It was thus interpreted that the cocoon yield was better from the worms fed on G-1 group than the G-2 group of cultivars. S-1635 mulberry variety performed better in terms of leaf productivity under the irrigated conditions. The average cocoon productivity was recorded more with silk worms fed on S-1635 and S-146 (Kanta, 2014). Quality of mulberry leaves influences growth, development of mulberry silk worm and greatly affects the economics of sericulture industry. It is necessity to promote intercropping of mulberry with all cereal crops, vegetables and fodder crops is possible (Raja, 1997). However, length and breadth measurements of pupae, obtained from different cultivars of mulberry did not reveal a demonstrable impact pupal size of silkworm. Further research is required to evaluate these varieties of mulberry by comparing the bioassay with chemical analysis of mulberry leaves.

\section{Acknowledgements}

The authors are grateful to the Dean, UCoA, Guru Kashi University, Talwandi Sabo (BTI) for providing funding and other research facilities to carry out this investigation.
Appropriate actions and advice of the Department of Horticulture (Sujanpur), for supplying mulberry saplings and Central Sericulture Board, Dehradun, for sending silkworm eggs (dfls), are thankfully acknowledged.

\section{References}

Anonymous 2006. Annual sericulture report on cocoon production, Department of industry Govt. of H.P, Shimla.

Bohidar, K., Sahoo, B. S.\& Singh, D. K. 2007. Effect of different varieties of mulberry leaves on economic parameters of the silkworm Bombyx mori, L under Orissa climate. Bull Ind Acad Sci., 11, 60-64.

Das, P. K. and Vijayaraghavan, K. 1990. Studies on the effect of different mulberry varieties and seasons on the larval development and cocoon characters of silkworm Bombyx mori L. Indian J. Seric. 29: 44-53.

Dhar, A., Tyeel, M. K., Avasthi, V. K. and R. K. Pandey, 2014. Sericulture Technology Package for Punjab: 41 PP.

Jyothi, M., Pratap M., Thimma, N. S. 2014. Studies on biochemical constituents of different genotypes of Morus alba L. Int. J. Pharm Bio. Sci. 5: 835-840.

Kanta, S. 2014. Promoting of multiples silkworm rearing crops in Pathankot district of punjab. Int. J. Innovative Res. and Review 2 (4):114-118

Krishnaswami, R. 1986. Mulberry cultivation in south India. C. S. B. \& T. I., Mysore, Bulletin No. 1: 19 Pp.

Machii, H. and Katagiri, K. 1991. Varietal differences in nutritive value of mulberry leaves for rearing of silkworms. JARQ 25: 202-208.

Nagaraju, J. 2002. Application of genetic principles in improving silk production. Curr. Sci. 83: 409-415.

Panse, V. G and P. V. Sukhatme, 1967. 
Statistical Methods for Agricultural Workers. 2nd Edition, Indian Council of Agricultural Research, New Delhi.

Pillai, S. V. and Jolly, M. S. 1985. An evaluation on the quality of mulberry varieties raised under hill conditions and the crop results of Bombyx mori L. Indian L. Seric. 24: 48-52.

Rahmathulla, V. K., Haque, R. S. Z., Himanthraj, M. T., Vindhya, G. S., Rajan R. K. 2005. Food ingestion, assimilation and conversion efficiency of mulberry silkworm, Bombyx mori L. Int. J. Indust. Entomol. 11: 1-12.

Raja Ram. 1997. Sericigenous Fauna and Flora of Himachal Pradesh. Indian Silk (June):5-6.

Ruth, L., Choudhury, B. N., Subramanian, G. and Kumar, N. S. 2019. Effect of different mulberry plant varieties on growth and economic parameters of the silkworm Bombyx mori in Mizoram. Front Physiol. 2019; 10: 878.

Singh, B. 2019. Biology and Morphometry of silk worm, Bombyx mori (Lepidoptera: Bombycidae) in Talwandi Sabo, Punjab. M. Sc. Thesis, Submitted to the Guru Kashi University, 2019: 32 PP.

Sujathamma, P., Dandin, S.B. and Savitri, G. 2001. Quality evaluation of mulberry genotypes through bioassay under Rayalaseema conditions of Andhra Pradesh. Indian J Seri, 40, 27-34.

Sunday, Adeniyi. 2015. Influence of different varieties of mulberry leaves (Morus alba) on growth and cocoon performance of biovoltine strain of silkworm (Bombyx mori). Int. J. Biol. Chem. Sci. 9 (2): 751-757.

Yogananda-Murthy, V. N., Ramesh, H. L., Munirajappa. 2013. Impact of feed selected mulberry germplasm varieties on silkworm (Bombyx mori L.) through bioassay techniques for commercial exploitation. Asian J. Nat. App. Sci. 2: $56-64$.

\section{How to cite this article:}

Amanpreet Kaur, J. S. Brar and Karmjit Singh. 2020. Performance of Mulberry Varieties for their Suitability in Sericulture Int.J.Curr.Microbiol.App.Sci. 9(09): 2524-2531. doi: https://doi.org/10.20546/ijcmas.2020.909.316 